\title{
Comparison between Cyanoacrylate, Sutureless and Polypropylene Sutures in Mesh Fixation on Lichtenstein Tension free in repair of Open Inguinal Hernia Ahmed Abd El Aal Sultan, Mahmoud Saad Kamal Ismail, Mohamed Ibrahem ELAnany
}

Department of General Surgery, Faculty of Medicine, Al -Azhar University

Corresponding authors: Ahmed Abd El Aal Sultan, e-mail: dr.ahmedsultan@azhar.edu.eg

\begin{abstract}
Background: inguinal hernia repair is one of the most common operations in general surgery. The Lichtenstein tension-free operation has become gold standard in open inguinal hernia repair. Despite the low recurrence rates; postoperative pain and discomfort remain a problem for a large number of patients.

Aim of the work: the aim of this study is to compare between cyanoacrylate, sutureless and polypropylene sutures in mesh fixation on lichtenstein tension free in repair of open inguinal hernia regard as postoperative pain, infection, recurrence, \& cost benefit.

Methods: a total of thirty patients with primary unilateral uncomplicated inguinal hernia were randomized to undergo lichtenstein tension free hernioplasty, and were randomized using close envelope into three groups: Group A: Inguinal hernioplasty with mesh fixation using polypropylene sutures (10 patients), Group B: Inguinal hernioplasty with mesh fixation using cyanoacrylate glue (10 patients) and Group C: Inguinal hernioplasty with mesh placement without sutures (10 patients). Primary outcome was early and late postoperative pain. Secondary endpoints were use of painkillers after 24 hours, morbidity rate and recurrence rate. Follow-up time was 6 months. Results: significantly, less postoperative pain was reported in group $\mathbf{B}$ compared to the other two groups (A\&C). Additionally, trends toward a higher postoperative quality of life, a faster surgical procedure, and a shorter hospital stay and earlier return to daily activities were seen in patients within group(B).Clinical recurrence was reported in only one patient in Group $\mathbf{C}$ after a period of four months follow up postoperatively.

Conclusion: cyanoacrylate glue seemed to be a simple, original, reasonable, feasible, reproducible technique and competitive alternative to the standard tissue-penetrating meshfixation devices in open inguinal hernioplasty. It is accompanied by a reduction in chronic inguinal pain, with no increase in the early recurrence rate.
\end{abstract}

Keywords: Inguinal Hernia, Lichtenstein Inguinal Hernioplasty, Cyanoacrylate Glue, Mesh Fixation, Postoperative Pain.

\section{INTRODUCATION}

Inguinal hernia repair is one of the most common general surgical operations performed worldwide. More than a million inguinal hernia repairs are performed annuallyin the United States and Europe alone ${ }^{[1]}$. Since the introduction of the Bassini method in 1887, more than 70 types of pure tissue repair have been reported in the surgical literature. An unacceptable recurrence rate, prolonged postoperative pain and recovery time after tissue repair along with our understanding of the metabolic origin of inguinal hernias led to the concept of tension-free hernioplasty with mesh. The main categories of inguinal hernia repair are the open repairs and the laparoscopic repairs. In the open category, repair of the hernia is mainly achieved by tension-free mesh repair ${ }^{[2]}$.

Lichtenstein "tension-free" hernioplasty, described for the first time in 1989, became a widely accepted method due to its safety, easiness of learning and low recurrence rate, lichtenstein open tension-free mesh augmented repair postoperative pain and chronic postoperative pain syndromes still remain a problem ${ }^{[3]}$. The reports concerning application of glues in inguinal hernia repair are growing in number. In the first preliminary report, Canonico showed the

efficacy of mesh fixation with glue, and indicated the viability of a sutureless Lichtenstein procedure. We report our experience of glue mesh fixation compared to sutureless and polypropylene sutures in mesh fixation on Lichtenstein tension free in repair of open inguinal hernia ${ }^{[4]}$.

\section{AIM OF THE WORK}

The aim of this study is to compare between cyanoacrylate, sutureless and polypropylene sutures in mesh fixation on lichtenstein tension free in repair of open inguinal hernia regard as postoperative pain, infection, recurrence, $\&$ cost benefit.

\section{PATIENTS AND METHODS}

This was a prospective study which was done in Department of Surgery, EL-Hussein Hospital, ALAzhar University (Cairo) in the period from November 2017 to July 2018. It included 30 patients, 10 cases underwent inguinal hernioplasty with mesh fixation using polypropylene sutures (Group A), 10 cases underwent inguinal hernioplasty with mesh fixation using cyanoacrylate glue (Group B) and 10 cases underwent inguinal hernioplasty with mesh 
placement without sutures (Group C). An informed consent was taken from all patients with a follow up period up to 6 months. The study was approved by the appropriate ethical authority of the hospital.

\section{Inclusion criteria:}

Patients are between 22 years and below 60 years, patients fit for surgery with all organs functions within acceptable ranges and all patients who are mentally oriented and consented for joining this research study.

\section{Exclusion criteria:}

Bilateral and/or recurrent hernia, femoral hernia, emergency presentation, chronic steroid treatment, coagulation disorders, ongoing chemotherapy, connective tissue disorders and psychological or physical disorders that could affect the ability to feel and elaborate pain.

\section{Surgical Technique}

Anaesthesia: operations were under spinal anaesthesia, except the patients who refused spinal anaesthesia; they were operated under general anaesthesia.

Operation: all patients were operated with the same surgical technique (Lichtenstein tension-free hernioplasty) using a polypropylene mesh as prosthetic material. Identical surgical procedures were used for the three groups, apart from the method used to fix the mesh.

\section{Technique}

An inguinal incision of 5-6 cm was made to expose the external oblique aponeurosis. The upper and lower leaves of the external oblique muscle were largely separated from the underlying tissues in order to establish a space to allow the subsequent placing of the mesh. In all groups particular attention was paid for identification and preservation of theilio-inguinal, ilio-hypogastric and genital branch of genito-femoral nerve. The spermatic cord was then dissected and separated from the posterior wall. The cremasteric muscle was incised longitudinally. Two flaps were therefore isolated andresected. In the case of indirect oblique hernia, the sac was separated from the cord, resected and then closed with absorbable suture material. In the case of direct hernia, the sac was reduced with plication of the transversalis fascia. A $6 \times 11 \mathrm{~cm}$ polypropylene mesh was placed to overlap the floor of inguinal canal extending from the pubic tubercle to behind the spermatic cord above the internal inguinal ring, and overlapping both conjoint tendon and shelving part of inguinal ligament or pubic tract.

\section{Group A: Inguinal hernioplasty with mesh fixation using polypropylene sutures:}

Apex of the mesh was sutured to the pubic tubercle using a No. 2-0 polypropylene suture. Continuous sutures were used to join the lower border of the mesh to the free edge of the inguinal ligament, after an opening was made into its lower edge to accommodate the spermatic cord. The continuous suture was extended up for a distance $1.5 \mathrm{~cm}$ behind the cord. Interrupted polypropylene sutures were used to anchor the mesh to the conjoined tendon. Laterally to the spermatic cord, the upper flap of the mesh was sutured to the lower one with a single polypropylene stitch.

\section{Group B: Inguinal hernioplasty with mesh fixation using cyanoacrylate glue:}

Cyanoacrylate glue was applied by the use of specially syringe to cover the whole surface of the mesh using minimal amount of the glue $(0.5-2 \mathrm{ml})$; glue could be applied as drops at interrupted points over conjoint tendon, inguinal ligament and pubic tubercle. Lateral to the spermatic cord, the upper part of the mesh was flipped over the lower one and they were joined with one polypropylene stitch. The mesh was compressed against the inguinal floor for about 2 min.

Group C: Inguinal hernioplasty with mesh placement without sutures:

The inguinal region was prepared and a skin incision above and parallel to the medial three fifths of the inguinal ligament. External oblique aponeurosis is identified and incised along the direction of fibers. The ilioinguinal and the iliohypogastric nerves are identified and preserved. Spermatic cord is identified and gently separated from the posterior wall of the inguinal canal and became completely delivered and identification of its content including the hernia sac. Then herniotomy was done and removal of excess parts of the hernia sac. The hernia sac managed according to the Lichtenstein technique, herniotomy was done and removal of excess parts of the hernia sac. A $6 \times 11 \mathrm{~cm}$ polypropylene mesh was placed on the inguinal floor after its trailing to accommodate the inguinal floor and left in place without any sutures.

\section{Statistical analysis}

The results were statistically analyzed. Data were fed to the computer and analyzed using IBM SPSS software package version 20.0.(Armonk, NY: IBM Corp). Qualitative data were described using number and percent. The Kolmogorov-Smirnov test was used to verify the normality of distribution, quantitative data were described using range (minimum and maximum), mean, standard deviation and median. Significance of the obtained results was judged at the 5\% level. The used tests were Chi-square test: For categorical variables, to compare between different groups. Monte Carlo correction: Correction for chisquare when more than $20 \%$ of the cells have expected countless than 5. F-test (ANOVA): For normally distributed quantitative variables, to compare between more than two groups, and Post Hoc 
test (Tukey) for pairwise comparisons. Kruskal Wallis test: For abnormally distributed quantitative variables, to compare between more than two studied groups.

\section{RESULTS}

This study was a prospective, randomized, comparative study. It was held in Department of Surgery, ELHussein Hospital, AL-Azhar University (Cairo) on 30 cases who were attendant to outpatient surgery clinic for elective repair of uncomplicated inguinal hernia diagnosed clinically and confirmed by ultrasound on inguinoscrotal region. This study was carried out between November 2017 to July 2018.The 30 patients were categorized into thre groups according to the to the method of mesh fixation; 10 cases underwent inguinal hernioplasty with mesh fixation using polypropylene sutures (Group A), 10 cases underwent inguinal hernioplasty with mesh fixation using cyanoacrylate glue (Group B) and 10 cases underwent inguinal hernioplasty with mesh placement without sutures (Group C).

Table 1: Comparison between the three studied groups according to demographic data.

\begin{tabular}{|c|c|c|c|c|c|c|c|c|}
\hline & \multicolumn{2}{|c|}{$\begin{array}{l}\text { Group A } \\
(\mathbf{n}=\mathbf{1 0})\end{array}$} & \multicolumn{2}{|c|}{$\begin{array}{l}\text { Group B } \\
(n=10)\end{array}$} & \multicolumn{2}{|c|}{$\begin{array}{l}\text { Group C } \\
(n=10)\end{array}$} & \multirow[t]{2}{*}{ Test of Sig. } & \multirow[t]{2}{*}{$\mathbf{p}$} \\
\hline & No. & $\%$ & No. & $\%$ & No. & $\%$ & & \\
\hline $\begin{array}{l}\text { Sex } \\
\text { Male } \\
\text { Female }\end{array}$ & $\begin{array}{l}9 \\
1 \\
\end{array}$ & $\begin{array}{l}90.0 \\
10.0 \\
\end{array}$ & $\begin{array}{c}10 \\
0 \\
\end{array}$ & $\begin{array}{c}100.0 \\
0.0\end{array}$ & $\begin{array}{l}9 \\
1 \\
\end{array}$ & $\begin{array}{l}90.0 \\
10.0 \\
\end{array}$ & $\begin{array}{r}\chi^{2}= \\
1.312\end{array}$ & $\begin{array}{l}{ }_{\mathrm{pC}}^{\mathrm{M}}= \\
1.000\end{array}$ \\
\hline $\begin{array}{l}\text { Age (years) } \\
\text { Min. - Max. } \\
\text { Mean } \pm \text { SD. } \\
\text { Median } \\
\end{array}$ & \multicolumn{2}{|c|}{$\begin{array}{c}22.0-55.0 \\
35.60 \pm 11.54 \\
35.50\end{array}$} & \multicolumn{2}{|c|}{$\begin{array}{c}25.0-60.0 \\
40.30 \pm 13.04 \\
39.50\end{array}$} & \multicolumn{2}{|c|}{$\begin{array}{c}23.0-50.0 \\
34.60 \pm 11.06 \\
31.0\end{array}$} & $\begin{array}{r}\mathrm{F}= \\
0.653\end{array}$ & 0.528 \\
\hline $\begin{array}{l}\text { BMI }\left(\mathbf{k g} / \mathbf{m}^{2}\right) \\
\text { Min. - Max. } \\
\text { Mean } \pm \text { SD. } \\
\text { Median }\end{array}$ & \multicolumn{2}{|c|}{$\begin{array}{c}19.0-31.0 \\
24.80 \pm 5.20 \\
23.50\end{array}$} & \multicolumn{2}{|c|}{$\begin{array}{c}19.0-37.0 \\
25.90 \pm 6.79 \\
24.0\end{array}$} & \multicolumn{2}{|c|}{$\begin{array}{c}19.0-32.0 \\
27.40 \pm 5.08 \\
29.50\end{array}$} & $\begin{array}{c}\mathrm{F}= \\
0.516\end{array}$ & 0.603 \\
\hline
\end{tabular}
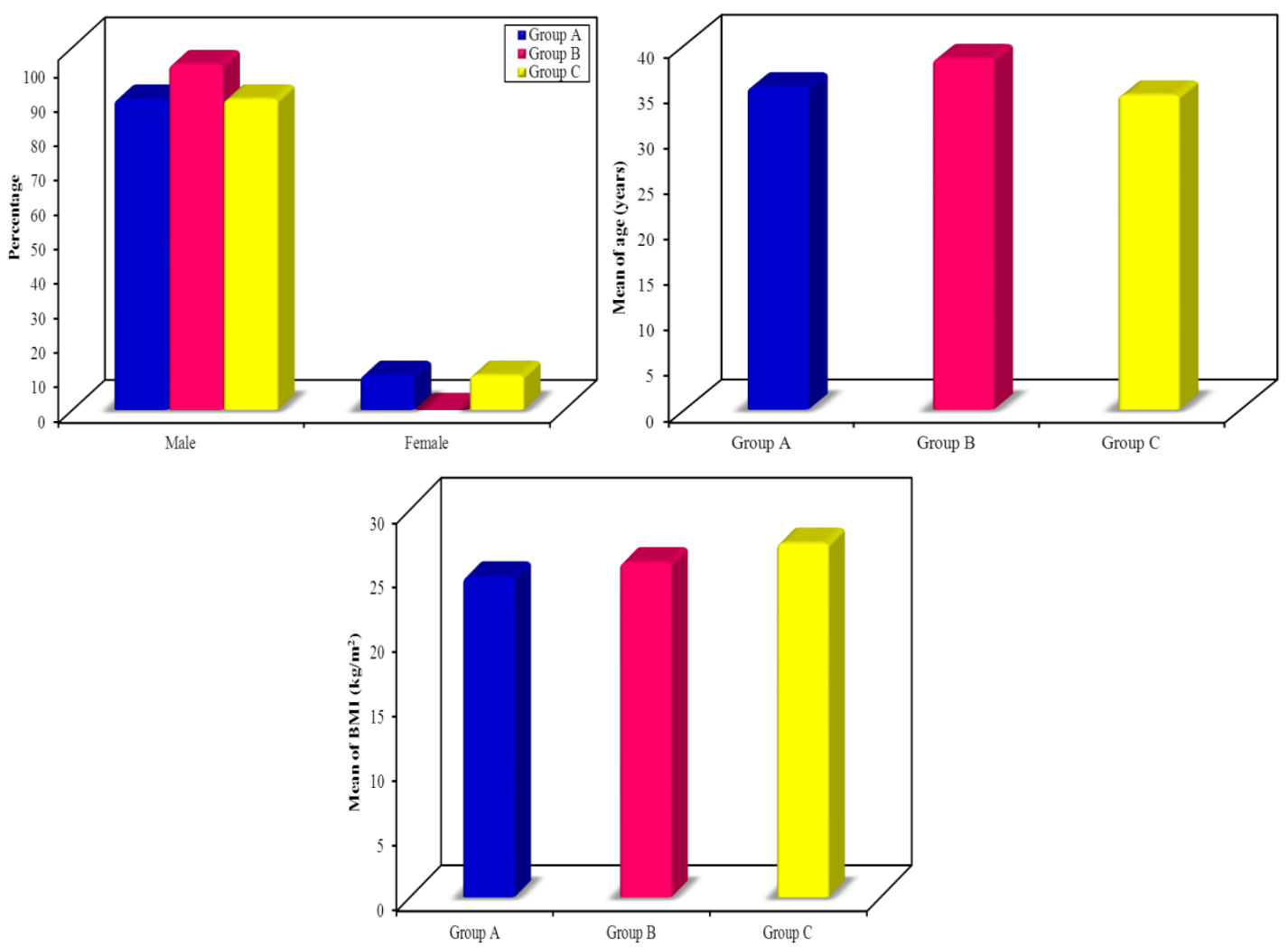

Figure 1: Comparison between the three studied groups according to Sex, Age (years) and BMI $\left(\mathrm{kg} / \mathrm{m}^{2}\right)$. 
Table 2: Comparison between the three studied groups according to type of hernia.

\begin{tabular}{|c|c|c|c|c|c|c|c|c|}
\hline & \multicolumn{2}{|c|}{$\begin{array}{l}\text { Group A } \\
(n=10)\end{array}$} & \multicolumn{2}{|c|}{$\begin{array}{l}\text { Group B } \\
(\mathbf{n}=\mathbf{1 0})\end{array}$} & \multicolumn{2}{|c|}{$\begin{array}{l}\text { Group C } \\
(n=10)\end{array}$} & \multirow[t]{2}{*}{$\chi^{2}$} & \multirow[t]{2}{*}{${ }^{\mathrm{MC}} \mathbf{p}$} \\
\hline & No. & $\%$ & No. & $\%$ & No. & $\%$ & & \\
\hline $\begin{array}{l}\text { Type hernia } \\
\text { Indirect } \\
\text { Direct }\end{array}$ & $\begin{array}{l}9 \\
1\end{array}$ & $\begin{array}{c}90.0 \\
10.0\end{array}$ & $\begin{array}{l}8 \\
2\end{array}$ & $\begin{array}{l}80.0 \\
20.0\end{array}$ & $\begin{array}{l}9 \\
1\end{array}$ & $\begin{array}{l}90.0 \\
10.0\end{array}$ & 0.747 & 1.000 \\
\hline
\end{tabular}

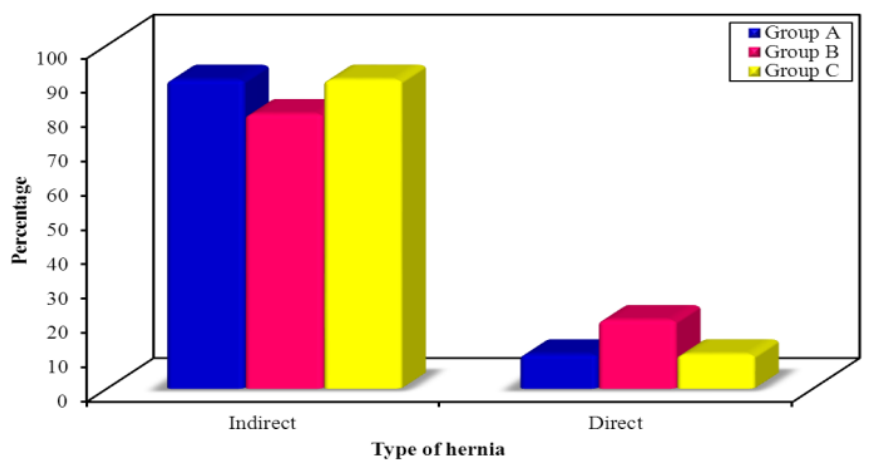

Figure (2): Comparison between the three studied groups according to type hernia.

Table (3): Comparison between the three studied groups according to Other side previous repair.

\begin{tabular}{|c|c|c|c|c|c|c|c|c|}
\hline & \multicolumn{2}{|c|}{$\begin{array}{l}\text { Group A } \\
(\mathbf{n}=\mathbf{1 0})\end{array}$} & \multicolumn{2}{|c|}{$\begin{array}{l}\text { Group B } \\
(\mathbf{n}=\mathbf{1 0})\end{array}$} & \multicolumn{2}{|c|}{$\begin{array}{l}\text { Group C } \\
(n=10)\end{array}$} & \multirow[t]{2}{*}{$\chi^{2}$} & \multirow[t]{2}{*}{${ }^{\mathrm{MC}} \mathbf{p}$} \\
\hline & No. & $\%$ & No. & $\%$ & No. & $\%$ & & \\
\hline $\begin{array}{l}\text { Other side previous repair } \\
\text { No } \\
\text { Yes }\end{array}$ & $\begin{array}{l}8 \\
2\end{array}$ & $\begin{array}{l}80.0 \\
20.0\end{array}$ & $\begin{array}{l}9 \\
1\end{array}$ & $\begin{array}{l}90.0 \\
10.0\end{array}$ & $\begin{array}{l}9 \\
1\end{array}$ & $\begin{array}{l}90.0 \\
10.0\end{array}$ & 0.747 & 1.000 \\
\hline
\end{tabular}

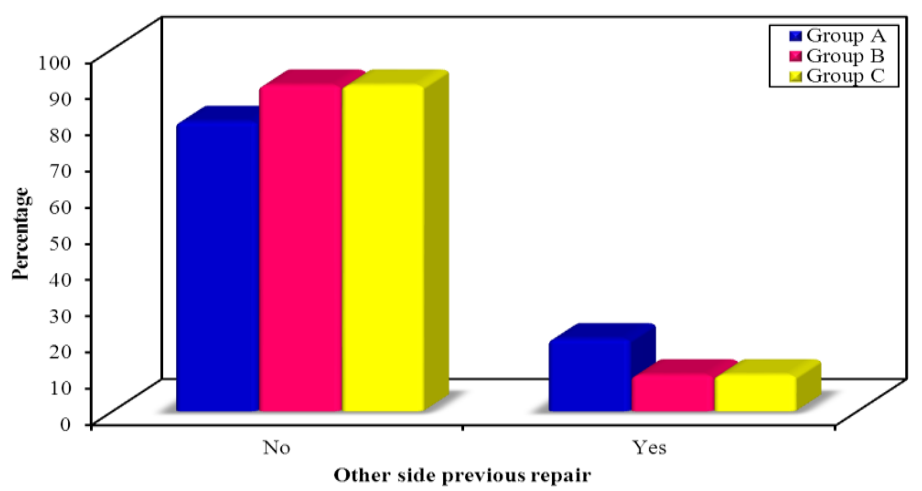

Figure 3: Comparison between the three studied groups according to Other side previous repair.

Group A: Ten patients underwent inguinal hernioplasty with mesh fixation using polypropylene sutures, their age ranged from 22-55 years with a mean of $35.60 \pm 11.54$ and a median of 35.50. Seven patients (70\%) had a right sided hernia while three patients (30\%) had a left side one. Nine patients (90\%) had an IIH while only one patient $(10 \%)$ had a DIH. Two patients $(20 \%)$ had a history of other side hernia repair using Prolene $^{\circledR}$ mesh. Group B: Ten patients underwent inguinal hernioplasty with mesh fixation using (Cyanoacrylte) glue, their age ranged from 25-60 years with a mean of $40.30 \pm 13.04$ and a median of

39.50. Seven patients $(70 \%)$ had a right side hernia while three patients $(30 \%)$ had a left side one. Eight of them $(80 \%)$ had an IIH while two patients $(20 \%)$ had a DIH. One patient (10\%) had a history of other side 


\section{Ahmed Abd El Aal Sultan et al.}

hernia repair with Prolene ${ }^{\circledR}$ mesh. Group C: Ten patients underwent inguinal hernioplasty with mesh placement without sutures, their age ranged from 23-50 years with a mean of $34.60 \pm 11.06$ and a median of 31.0. Seven patients $(70 \%)$ had a right side hernia while three patients (30\%) had a left side one. Nine of them (90\%) had an IIH while only one patients (10\%) had a

Table (4): Comparison between the three studied groups according to surgical and medical history.

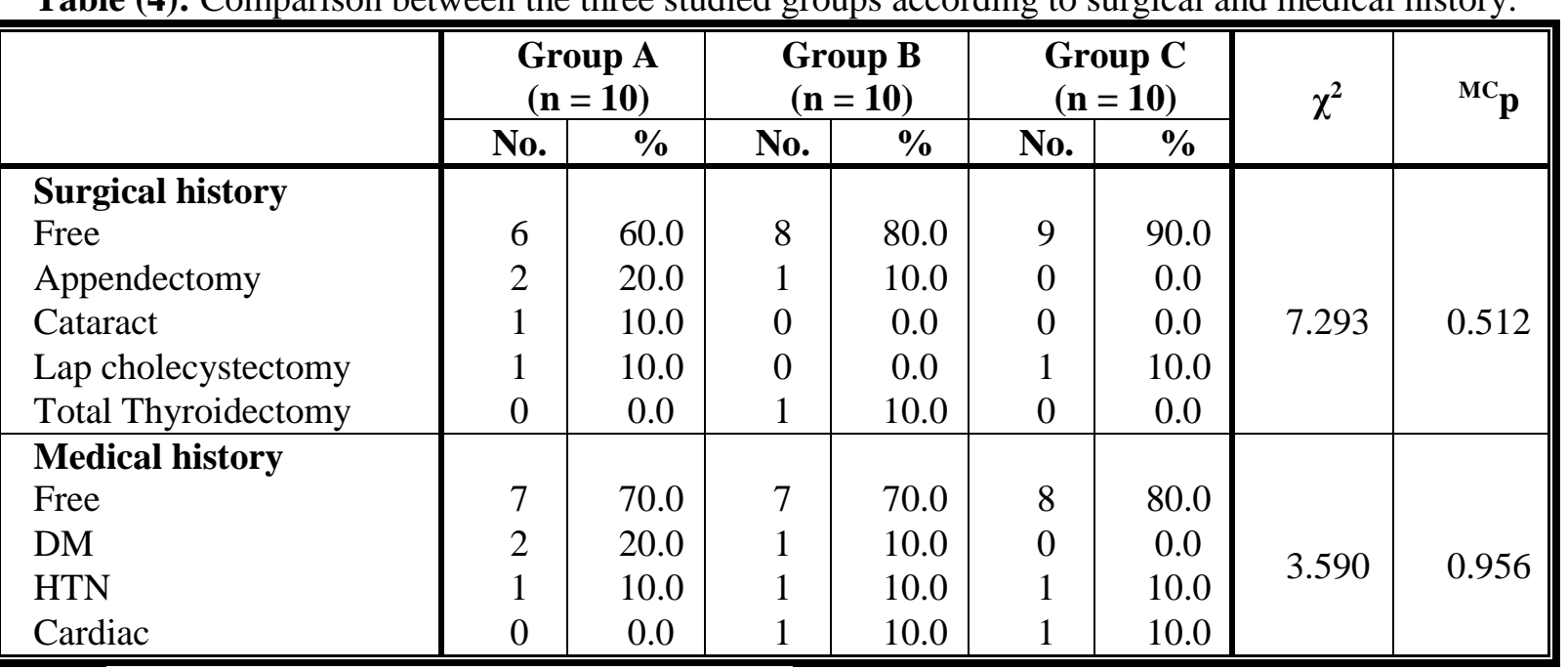
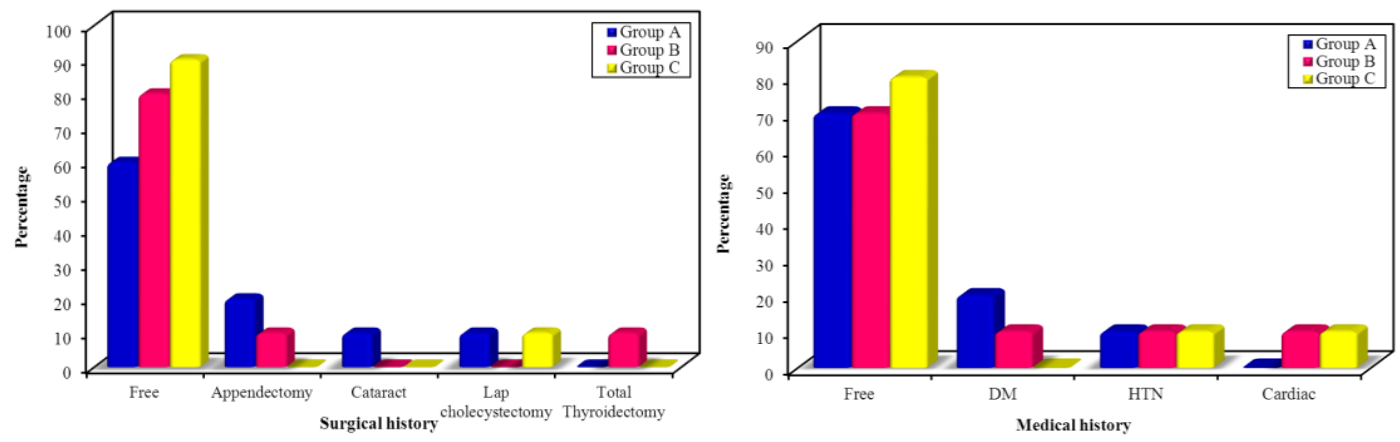

Figure (4): Comparison between the three studied groups according to surgical and medical history.

As regard medical history, there was no statistically significant difference between the three groups, $\mathrm{p}=$ 0.956. As regard surgical history, there was no statistically significant difference between the three groups, $\mathrm{p}=$ 0.512 (table 4). 
Table (5): Comparison between the three studied groups according to surgical technique.

\begin{tabular}{|c|c|c|c|c|c|c|c|c|}
\hline \multirow{2}{*}{ Surgical technical } & \multicolumn{2}{|c|}{$\begin{array}{c}\text { Group A } \\
(\mathbf{n}=\mathbf{1 0})\end{array}$} & \multicolumn{2}{|c|}{$\begin{array}{c}\text { Group B } \\
(\mathbf{n}=\mathbf{1 0})\end{array}$} & \multicolumn{2}{|c|}{$\begin{array}{c}\text { Group C } \\
(\mathbf{n}=\mathbf{1 0})\end{array}$} & \multirow[t]{2}{*}{ Test of Sig. } & \multirow[t]{2}{*}{$\mathbf{p}$} \\
\hline & No. & $\%$ & No. & $\%$ & No. & $\%$ & & \\
\hline $\begin{array}{l}\text { Technical difficulties } \\
\text { No } \\
\text { Yes }\end{array}$ & $\begin{array}{l}9 \\
1\end{array}$ & $\begin{array}{l}90.0 \\
10.0\end{array}$ & $\begin{array}{l}9 \\
1\end{array}$ & $\begin{array}{c}90.0 \\
10.0\end{array}$ & $\begin{array}{l}9 \\
1\end{array}$ & $\begin{array}{l}90.0 \\
10.0\end{array}$ & $\begin{array}{c}\chi^{2}= \\
0.436\end{array}$ & $\begin{array}{l}{ }^{\mathrm{MC}} \mathrm{p}= \\
1.000\end{array}$ \\
\hline $\begin{array}{l}\text { Surgeon satisfaction } \\
\text { No } \\
\text { Yes }\end{array}$ & $\begin{array}{l}1 \\
9\end{array}$ & $\begin{array}{l}10.0 \\
90.0\end{array}$ & $\begin{array}{l}1 \\
9\end{array}$ & $\begin{array}{l}10.0 \\
90.0\end{array}$ & $\begin{array}{l}1 \\
9\end{array}$ & $\begin{array}{l}10.0 \\
90.0\end{array}$ & $\begin{array}{c}\chi^{2}= \\
0.436\end{array}$ & $\begin{array}{l}{ }^{\mathrm{MC}} \mathrm{p}= \\
1.000\end{array}$ \\
\hline $\begin{array}{l}\text { Operative time (min.) } \\
\text { Min. - Max. } \\
\text { Mean } \pm \text { SD. } \\
\text { Median }\end{array}$ & \multicolumn{2}{|c|}{$\begin{array}{c}60.0-105.0 \\
81.60 \pm 13.67 \\
82.0\end{array}$} & \multicolumn{2}{|c|}{$\begin{array}{c}40.0-100.0 \\
69.80 \pm 20.38 \\
75.0\end{array}$} & \multicolumn{2}{|c|}{$\begin{array}{c}35.0-90.0 \\
58.30 \pm 20.04 \\
54.50\end{array}$} & $\begin{array}{c}\mathrm{F}= \\
4.056^{*}\end{array}$ & $0.029^{*}$ \\
\hline Sig. bet grps. & \multicolumn{6}{|c|}{$\mathrm{p}_{1}=0.334, \mathrm{p}_{2}=0.022^{*}, \mathrm{p}_{3}=0.352$} & & \\
\hline $\begin{array}{l}\text { Mesh fixation time (min.) } \\
\text { Min. - Max. } \\
\text { Mean } \pm \text { SD. } \\
\text { Median }\end{array}$ & \multicolumn{2}{|c|}{$\begin{array}{c}11.0-22.0 \\
16.60 \pm 3.60 \\
16.50\end{array}$} & \multicolumn{2}{|c|}{$\begin{array}{c}2.0-6.0 \\
4.0 \pm 1.33 \\
4.0\end{array}$} & \multicolumn{2}{|c|}{$\begin{array}{l}2.50-5.0 \\
3.60 \pm 0.88 \\
3.25\end{array}$} & $\begin{array}{c}\mathrm{F}= \\
105.933^{*}\end{array}$ & $<0.001^{*}$ \\
\hline Sig. bet grps. & \multicolumn{6}{|c|}{$\mathrm{p}_{1}<0.001^{*}, \mathrm{p}_{2}<0.001^{*}, \mathrm{p}_{3}=0.918$} & & \\
\hline $\begin{array}{l}\text { Nerves } \\
\text { Cut } \\
\text { Not clear } \\
\text { Preserved }\end{array}$ & $\begin{array}{l}2 \\
0 \\
8\end{array}$ & $\begin{array}{c}20.0 \\
0.0 \\
80.0\end{array}$ & $\begin{array}{l}1 \\
1 \\
8\end{array}$ & $\begin{array}{l}10.0 \\
10.0 \\
80.0\end{array}$ & $\begin{array}{l}1 \\
2 \\
7\end{array}$ & $\begin{array}{l}10.0 \\
20.0 \\
70.0\end{array}$ & $\begin{array}{c}\chi^{2}= \\
2.580\end{array}$ & $\begin{array}{l}{ }^{\mathrm{MC}} \mathrm{p}= \\
0.879\end{array}$ \\
\hline $\begin{array}{l}\text { Repair of posterior wall } \\
\text { No } \\
\text { Yes }\end{array}$ & $\begin{array}{l}8 \\
2 \\
\end{array}$ & $\begin{array}{l}80.0 \\
20.0 \\
\end{array}$ & $\begin{array}{l}7 \\
3 \\
\end{array}$ & $\begin{array}{l}70.0 \\
30.0\end{array}$ & $\begin{array}{l}8 \\
2 \\
\end{array}$ & $\begin{array}{l}80.0 \\
20.0 \\
\end{array}$ & $\begin{array}{c}\chi^{2}= \\
0.511\end{array}$ & $\begin{array}{l}{ }^{\mathrm{MC}} \mathrm{p}= \\
1.000\end{array}$ \\
\hline $\begin{array}{l}\text { Cremastric muscle } \\
\text { Preserved } \\
\text { Cut }\end{array}$ & $\begin{array}{l}9 \\
1 \\
\end{array}$ & $\begin{array}{l}90.0 \\
10.0\end{array}$ & $\begin{array}{l}8 \\
2 \\
\end{array}$ & $\begin{array}{l}80.0 \\
20.0\end{array}$ & $\begin{array}{l}7 \\
3 \\
\end{array}$ & $\begin{array}{l}70.0 \\
30.0\end{array}$ & $\begin{array}{c}\chi^{2}= \\
1.278\end{array}$ & $\begin{array}{l}{ }_{\mathrm{pC}}^{\mathrm{MC}}= \\
0.849\end{array}$ \\
\hline $\begin{array}{l}\text { Drain } \\
\text { No }\end{array}$ & 8 & 80.0 & 9 & 90.0 & 10 & 100.0 & $\begin{array}{c}\chi^{2}= \\
2.033\end{array}$ & $\begin{array}{l}{ }_{\mathrm{MC}}^{\mathrm{p}}= \\
0.758\end{array}$ \\
\hline
\end{tabular}

As regards to the time needed for mesh fixation, in group $\mathbf{A}$, the mesh fixation time ranged from $11.0-22.0$ minutes with a mean of $(16.60 \pm 3.60)$ and a median of (16.50). In Group $\mathbf{B}$ the time ranged from $2.0-6.0$ minutes with a mean of $4.0 \pm 1.33$ and a median of 4.0whereas in Group $\mathbf{C}$ the time ranged from $2.50-5.0$ minutes with a mean of $3.60 \pm 0.88$ and a median of 3.25.There was a statistical significant difference between the three groups. The mesh fixation time was significantly shorter in group $C$ with $p$ value $={ }^{\mathrm{MW}} \mathrm{p}<<0.001^{*}$. The total operative time in group $\mathbf{C}$ was significantly shorter than in group A \&group B with $\mathrm{p}$ value $={ }^{\mathrm{MW}} \mathrm{p}<0.029^{*}$. The difference between the three groups as regard to operative time is illustrated in table 5. In Group A, the technical difficulties presented in only one patient (10\%), was obese patient who needed longer time for dissection with an operative time reached 100 minutes and mesh fixation time of 15 minutes. The technical difficulties in Group B, was encountered in only one patient (10\%), was obese and had disturbed anatomy. The overall operative time for this patient was 80 minutes while time needed for 


\section{Ahmed Abd El Aal Sultan et al.}

mesh fixation was 4 minutes. The technical difficulties in Group $\mathbf{C}$, was encountered in only one patient $(10 \%)$. The overall operative time for this patient was 90 minutes while time needed for mesh fixation was 5 minutes.As the surgeons were yet not familiar with placement and fixation of the mesh without any sutures and its handling earlier in our study. There was no statistical significance between the three groups as regard technical difficulties as illustrated in table 5.The surgeons were almost equally satisfied with the procedure in the three groups (in $90 \%$ of patients in each group). There was no statistical significant difference between the three groups as illustrated in table 5. In Group A, The surgeon recorded being unsatisfied in one case $(10 \%)$. The patient was obese which made the view, dissection and mesh fixation more difficult which was reflected on the overall operative time. In Group B, The surgeon recorded being unsatisfied in one case $(10 \%)$ earlier in the study when he was still not so familiar with the glue used for fixation which adheres tightly and rapidly to the underlying tissues making any trial for re-positioning was quite difficult. In this case we used two ampoules of glue for fixation. In Group $\mathbf{C}$, the surgeon recorded being unsatisfied in one case $(10 \%)$ earlier in the study when he was still not so familiar with placement and fixation of the mesh without any sutures and its handling earlier in our study. The Cremasteric muscle was cut in one patient (10\%) in Group A, also in two patients $(20 \%)$ in Group B and in three patients $(30 \%)$ in Group $\mathbf{C}$ for better positioning of the mesh. The two nerves (Ilio-inguinal and genital branch of Genitofemoral nerve) were identified and preserved in eight patients (80\%) in Group A, while accidental cutting of the Ilioinguinal nerve occurred in two patients (20\%). In Group $\mathbf{B}$, the nerves were identified and preserved in eight patients $(80 \%)$. while accidental cutting of the Ilioinguinal nerve occurred in only one patient (10\%).while clear identification of the two nerves failed in only one patient (10\%). In Group C, the nerves were identified and preserved in seven patients $(70 \%)$. while accidental cutting of the Ilioinguinal nerve occurred in only one patient $(10 \%)$. While clear identification of the two nerves failed in two patients $(20 \%)$. The post wall was weak and required a repair in Group A in two patients (20\%), in Group B in three patients (30\%) and in Group $\mathbf{C}$ in two patients (20\%). There was no statistical significant difference between the three groups as regard nerves preservation, cremasteric muscle cutting and the post wall repair. As regard to negative suction drain application intraoperatively in Group A in two patients (20\%), in Group B in only one patients (10\%) and in Group C no patient $(0 \%)$. There was no statistical significant difference between the three groups as regard to negative suction drain.

Table (6): Comparison between the three studied groups according to postoperative complications.

\begin{tabular}{|c|c|c|c|c|c|c|c|c|}
\hline \multirow[t]{2}{*}{ Post-operative Complications } & \multicolumn{2}{|c|}{$\begin{array}{c}\text { Group A } \\
(\mathbf{n}=10)\end{array}$} & \multicolumn{2}{|c|}{$\begin{array}{c}\text { Group B } \\
(\mathbf{n}=\mathbf{1 0})\end{array}$} & \multicolumn{2}{|c|}{$\begin{array}{c}\text { Group C } \\
(\mathbf{n}=10)\end{array}$} & \multirow[t]{2}{*}{$\chi^{2}$} & \multirow[t]{2}{*}{${ }^{\mathrm{MC}} \mathbf{p}$} \\
\hline & No. & $\%$ & No. & $\%$ & No. & $\%$ & & \\
\hline Wound infection & 2 & 20.0 & 1 & 10.0 & 1 & 10.0 & 0.747 & 1.000 \\
\hline Seroma & 2 & 20.0 & 1 & 10.0 & 1 & 10.0 & 0.747 & 1.000 \\
\hline Hematoma & 2 & 20.0 & 0 & 0.0 & 1 & 10.0 & 2.033 & 0.758 \\
\hline Urine refection & 0 & 0.0 & 0 & 0.0 & 0 & 0.0 & - & - \\
\hline Scroral edema & 2 & 20.0 & 1 & 10.0 & 1 & 10.0 & 0.747 & 1.000 \\
\hline Hypothesia & 3 & 30.0 & 1 & 10.0 & 3 & 30.0 & 1.557 & 0.648 \\
\hline F.B sensation & 2 & 20.0 & 0 & 0.0 & 1 & 10.0 & 2.033 & 0.758 \\
\hline
\end{tabular}

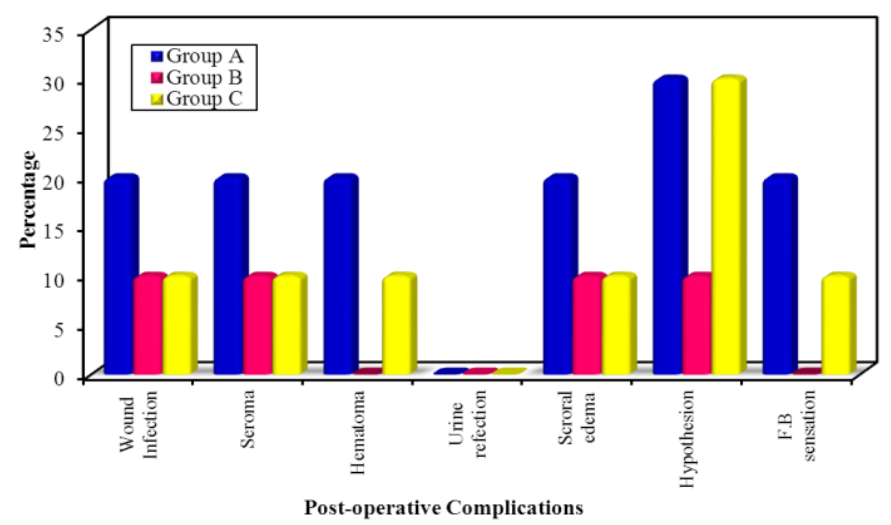


Comparison between Cyanoacrylate, Sutureless and...

Figure (5): Comparison between the three studied groups according to postoperative complications.

Superficial Wound infection occurred in two patients (20\%) in group A, one patient (10\%) in group B and one patient $(10 \%)$ in group C. All of them responded well to antibiotics. Scrotal edema encountered in two patients (20\%) in group A, one patient (10\%) in group B and one patient (10\%) in group $\mathbf{C}$ and resolved spontaneously within 2 weeks postoperatively. As regard to F.B sensation reported in two patients (20\%) in group A, there is no reported case in group $\mathbf{B}(0.0 \%)$ and one patient $(10 \%)$ in group $\mathbf{C}$ (after 3 months) in the three groups.

Table (7): Comparison between the three studied groups according to post operative pain "VAS"

\begin{tabular}{|c|c|c|c|c|c|}
\hline Pain "VAS" & $\begin{array}{c}\text { Group A } \\
(\mathbf{n}=\mathbf{1 0})\end{array}$ & $\begin{array}{c}\text { Group B } \\
(\mathbf{n}=\mathbf{1 0})\end{array}$ & $\begin{array}{c}\text { Group C } \\
(\mathbf{n}=\mathbf{1 0})\end{array}$ & $\mathbf{H}$ & $\mathbf{p}$ \\
\hline $\begin{array}{l}\text { 1'day } \\
\text { Min. - Max. } \\
\text { Mean } \pm \text { SD. } \\
\text { Median }\end{array}$ & $\begin{array}{c}4.0-9.0 \\
6.0 \pm 2.58 \\
4.0\end{array}$ & $\begin{array}{c}2.0-4.0 \\
2.60 \pm 0.70 \\
2.50\end{array}$ & $\begin{array}{c}3.0-6.0 \\
3.70 \pm 1.06 \\
3.0\end{array}$ & $.103^{*}$ & p.001* \\
\hline Sig. bet grps. & \multicolumn{3}{|c|}{$\mathrm{p}_{1}<0.001^{*}, \mathrm{p}_{2}=0.035^{*}, \mathrm{p}_{3}=0.043^{*}$} & & \\
\hline $\begin{array}{l}2 \text { Week } \\
\text { Min. - Max. } \\
\text { Mean } \pm \text { SD. } \\
\text { Median }\end{array}$ & $\begin{array}{c}3.0-10.0 \\
5.80 \pm 3.61 \\
3.0\end{array}$ & $\begin{array}{c}1.0-3.0 \\
2.30 \pm 0.82 \\
2.50\end{array}$ & $\begin{array}{c}1.0-7.0 \\
2.80 \pm 1.81 \\
3.00\end{array}$ & $672^{*}$ & $.013^{*}$ \\
\hline Sig. bet grps. & \multicolumn{3}{|c|}{$\mathrm{p}_{1}=0.005^{*}, \mathrm{p}_{2}=0.028^{*}, \mathrm{p}_{3}=0.548$} & & \\
\hline $\begin{array}{l}1 \text { Month } \\
\text { Min. - Max. } \\
\text { Mean } \pm \text { SD. } \\
\text { Median }\end{array}$ & $\begin{array}{c}0.0-9.0 \\
7.0 \pm 3.46 \\
8.50\end{array}$ & $\begin{array}{c}0.0-4.0 \\
1.90 \pm 0.99 \\
2.0\end{array}$ & $\begin{array}{c}0.0-8.0 \\
2.50 \pm 2.64 \\
1.0\end{array}$ & $.519^{*}$ & $.014^{*}$ \\
\hline Sig. bet grps. & \multicolumn{3}{|c|}{$\mathrm{p}_{1}=0.020^{*}, \mathrm{p}_{2}=0.007^{*}, \mathrm{p}_{3}=0.707$} & & \\
\hline $\begin{array}{l}2 \text { Month } \\
\text { Min. - Max. } \\
\text { Mean } \pm \text { SD. } \\
\text { Median }\end{array}$ & $\begin{array}{c}0.0-7.0 \\
2.70 \pm 2.95 \\
1.50\end{array}$ & $\begin{array}{c}0.0-0.0 \\
0.0 \pm 0.0 \\
0.0\end{array}$ & $\begin{array}{c}0.0-6.0 \\
1.40 \pm 1.78 \\
1.0\end{array}$ & $.132^{*}$ & $.006^{*}$ \\
\hline Sig. bet grps. & \multicolumn{3}{|c|}{$\mathrm{p}_{1}=0.004^{*}, \mathrm{p}_{2}=0.800, \mathrm{p}_{3}=0.900^{*}$} & & \\
\hline $\begin{array}{l}6 \text { Month } \\
\text { Min. - Max. } \\
\text { Mean } \pm \text { SD. } \\
\text { Median }\end{array}$ & $\begin{array}{c}0.0-5.0 \\
2.70 \pm 2.41 \\
3.50\end{array}$ & $\begin{array}{c}0.0-0.0 \\
0.0 \pm 0.0 \\
0.0\end{array}$ & $\begin{array}{c}0.0-3.0 \\
1.0 \pm 1.15 \\
0.50\end{array}$ & .560 & $.008^{*}$ \\
\hline Sig. bet grps. & \multicolumn{3}{|c|}{$\mathrm{p}_{1}=0.002^{*}, \mathrm{p}_{2}=0.195, \mathrm{p}_{3}=0.075$} & & \\
\hline
\end{tabular}

As regard to pain, evaluation of the postoperative pain was done using the VAS as illustrated in table (7). In group A, the pain score in the first post-operative day ranged from $4.0-9.0$ with a mean of $6.0 \pm 2.58$ and a median of 4.0. In group B, it ranged from $2.0-4.0$ with a mean of $2.60 \pm 0.70$ and a median of 2.50. And in group $\mathbf{C}$, it ranged from $3.0-6.0$ with a mean of $3.70 \pm 1.06$ and a median of 3.0.The pain score was significantly higher in Group B in comparison to Group A\& Group $\mathbf{C}$ with a $\mathrm{P}$ value $=\mathrm{p}<0.001$. In group $\mathbf{A}$, the pain score in two weeks post-operative ranged from $3.0-10.0$ with a mean of $5.80 \pm 3.61$ and a median of 3.0. In group $\mathbf{B}$, it ranged from 1.0
- 3.0with a mean of $2.30 \pm 0.82$ and a median of 2.50. And in group $\mathbf{C}$, it ranged from $1.0-7.0$ with a mean of $2.80 \pm 1.81$ and a median of 3.0. The pain score was significantly lower in Group $\mathbf{B}$ in comparison to Group A\& Group $\mathbf{C}$ with a $\mathrm{P}$ value $=$ $\mathrm{p}=0.013$. In group $\mathbf{A}$, the pain score in one month post-operative ranged from $0.0-9.0$ with a mean of $7.0 \pm 3.46$ and a median of 8.50. In group $\mathbf{B}$, it ranged from $0.0-4.0$ with a mean of $1.90 \pm 0.99$ and a median of 2.0. And in group $\mathbf{C}$, it ranged from $0.0-8.0$ with a mean of $2.50 \pm 2.64$ and a median of 1.0. The pain score was significantly lower in Group B in comparison to Group A\& Group $\mathbf{C}$ with a $\mathbf{P}$ value $=p=0.014$. In group $\mathbf{A}$, the pain score in two 
Ahmed Abd El Aal Sultan et al.

months post-operative day ranged from $0.0-7.0$ with a mean of $2.70 \pm 2.95$ and a median of 1.50 . In group B, it ranged from $0.0-0.0$ with a mean of 0.0 -0.0 and a median of 0.0. And in group $\mathbf{C}$, it ranged from $0.0-6.0$ with a mean of $1.40 \pm 1.78$ and a median of 1.0. The pain score was significantly lower in Group $\mathbf{B}$ in comparison to Group $\mathbf{A} \&$ Group $\mathbf{C}$ with a $\mathbf{P}$ value $=p=0.006$ as illustrated in table (7). No additive analgesia needed in the three groups in early post-operative period. While six patients in group $\mathbf{A}$, only two patients in group $\mathbf{B}$ and five patients in group $\mathbf{C}$ needed mild analgesia in first two weeks post-operative. As regards to Group B, the ten patients (100\%) showed a gradual improvement of pain and became a pain free by the $2^{\text {nd }}$ month post-operative.

Table (8): Comparison between the three studied groups according to recurrence.

\begin{tabular}{|c|c|c|c|c|c|c|c|c|}
\hline & \multicolumn{2}{|c|}{$\begin{array}{c}\text { Group A } \\
(\mathbf{n}=\mathbf{1 0})\end{array}$} & \multicolumn{2}{|c|}{$\begin{array}{c}\text { Group B } \\
(\mathbf{n}=\mathbf{1 0})\end{array}$} & \multicolumn{2}{|c|}{$\begin{array}{c}\text { Group C } \\
(n=10)\end{array}$} & \multirow[t]{2}{*}{$\square^{2}$} & \multirow[t]{2}{*}{${ }^{\mathrm{MC}} \mathbf{p}$} \\
\hline & No. & $\%$ & No. & $\%$ & No. & $\%$ & & \\
\hline $\begin{array}{l}\text { Recurrence } \\
\text { No }\end{array}$ & 10 & 100.0 & 10 & 100.0 & 9 & 90.0 & 1885 & 1000 \\
\hline Yes & 0 & 0.0 & 0 & 0.0 & 1 & 10.0 & 1.885 & 1.000 \\
\hline
\end{tabular}

As regard to hernia recurrence reported in only one patient (10\%) in group $\mathbf{C}$ (after 4 months), there is no reported cases in group $\mathbf{A}(0.0 \%)$ and in group $\mathbf{B}(0.0 \%)$ (after 6 months).

Table (9): Comparison between the three studied groups according to hospital stay(hours).

\begin{tabular}{||l|c|c|c|c|c||}
\hline & $\begin{array}{c}\text { Group A } \\
(\mathbf{n = 1 0})\end{array}$ & $\begin{array}{c}\text { Group B } \\
(\mathbf{n = 1 0})\end{array}$ & $\begin{array}{c}\text { Group C } \\
(\mathbf{n = 1 0})\end{array}$ & H & p \\
\hline Hospital stay (hour) & $12.0-48.0$ & $6.0-12.0$ & $12.0-48.0$ & & \\
Min. - Max. & $30.0 \pm 15.23$ & $9.30 \pm 2.45$ & $30.20 \pm 11.64$ & $18.212^{*}$ & $<0.001^{*}$ \\
Mean \pm SD. & 30.0 & 10.0 & 26.0 & & \\
Median & \multicolumn{2}{|c|}{$\mathrm{p}_{1}<0.001^{*}, \mathrm{p}_{2}=0.939, \mathrm{p}_{3}<0.001^{*}$} & & \\
\hline Sig. bet. grps. & \multicolumn{2}{|l|}{} & & \\
\hline
\end{tabular}

As regards to the hospital stay, in group $\mathbf{A}$ ranged from $12.0-48.0$ hour with a mean of $30.0 \pm 15.23$ and a median of 30.0 while in group $\mathbf{B}$ ranged from $6.0-12.0$ hour with a mean of $9.30 \pm 2.45$ and a median of 10.0and in group $\mathbf{C}$ ranged from12.0 - 48.0 hour with a mean of $30.20 \pm 11.64$ and a median of (26.0) with $\mathbf{P}$ value $=\mathrm{p}<0.001$ which is highly statistically significant for group $\mathbf{B}$.

\section{DISCUSSION}

Nearly 800000 patients undergo surgery for inguinal hernia repair in the United States each year, making this disease a major public health issue. Before the revolution of inguinal hernia repair by tension-free techniques about 20 years ago, traditional groin hernioplasty techniques i.e., Bassini, McVay and Shouldice were associated with a high rate of recurrence and a high rate of postoperative chronic pain because of the tension of the tissue. The main end-point for the evaluation of the treatment of inguinal hernia was the recurrence rate. In this respect, wall reinforcement with prosthetic mesh was clearly superior to simple herniorrhaphy. An improvement in postoperative comfort and a lower incidence of recurrence have been reported among patients repaired with tension-free techniques compared tonon-mesh techniques. Chronic pain was the most important complication associated with herniamesh repair. In fact, post hernioplasty pain can significantly influence the patient's quality of life ${ }^{[5]}$. This inguinal discomfort can include neuralgia (e.g.from the ilioinguinal and/or genitofemoral nerve), slight to serious inguinal pain, anaesthesia, and dysaesthesia. Because of the variability of these findings, it is very difficult to see a common aetiology. Possible explanations might be a periostal reaction due to the sutures atthe pubic tubercle, tension onmuscle fibres, or even their necrosis, or nerve compression due to the sutures at the upper end of the mesh, or a "foreign-body reaction" caused by the mesh itself ${ }^{[6]}$.

One step for achieving better results might be the avoidance of sutures to prevent any tension on the pubic tubercle, muscle fibres, and nerves. So we decided to glue the mesh onto the pelvic floor. The chosen glue was n-butyl-cyanoacrylate. Cyanoacrylates, it has been used as surgical tissue 
adhesive since the 1960s. Butyl-2-cyanoacrylate became a very popular surgical tissue adhesive because of its excellent binding strength and low histotoxicity. The indications range from pure experimental studies to everyday use, i.e., in gastroenterology (for sclerotherapy of esophageal and gastric varices), dental surgery, plastic and reconstructive surgery, and many others. Cyanoacrylate has been available for more than 30 years and was created for superficial wound closure.Although it was not designed for internal application,this glue is widely used in many different indications all over the world.The glue is easy to apply(from avial), dries within 5-7 seconds, has an excellent binding strength, and a low histotoxicity. Because of these properties, only a small amount (some drops at the edges of the mesh) of the product are needed ${ }^{[7]}$.

The successful use of cyanoacrylate in the different surgical disciplines was the motive to perform such a prospective, randomized controlled study to compare the efficacy of mesh fixation by cyanoacrylate, sutureless and polypropylene suture during one day surgery of open inguinal hernia repair and all patients were re-examined using a standardized questionnaire at 1week, 30 days, 3 months and 6 months after surgery. Regarding the type of mesh fixation, recent literatures review to establish an evidence base for cyanoacrylate glue in mesh fixation and based on this evidence several studies have eliminated the use of sutures in mesh fixation in an attempt to reduce chronic groin pain, this aims to avoid direct nerve irritation or nerve entrapment. On the other hand, mesh fixation with glue (tissue adhesive) seems an optimal choice to reduce postoperative pain. Accordingly, preliminary results published with different glues all showed promising results with reduced postoperative pain ${ }^{[8]}$.

In our study the advantage of mesh fixation using cyanoacrylate glue clearly emerged with respect to operative time which was significantly shorter in the cyanoacrylate glue group with a median of 75.0 minutes compared to median of 82.0 minutes in the standard polypropylene suturesgroup. The lack of requirement for sutures to secure the mesh reduced the operative time by about $10 \mathrm{~min}$. And operative time in sutureless group with median of 54.50 minutes.

The time needed for mesh fixation in Group B, reached $2.0-6.0$ minutes with a median of 4.0 compared to a median of 16.50 in Group $\mathbf{A}$, and Group $\mathbf{C}$ with a median of 3.25.

The superior tissue adherence of cyanoacrylate glue is also associated with certain disadvantages. It adheres very well immediately after contact with tissue; repositioning which required another ampoule, experience and immense patience. That was obvious earlier in our study when the surgeons weren't yet familiar with the glue and its handling.

Shorter surgery time may be beneficial in terms of overall cost and reduced infection rate. In our series; there were no reported cases with mesh infection.

The incidence of seroma in our study was $20 \%$ (2 patients) in group A, $10 \%$ (1 patient) in group B and $10 \%$ (1 patient) in group C. Two patients had an indirect inguinoscrotal hernia with larger sac that required more distal dissection and for that some may recommend for inguinoscrotal hernia, transecting the indirect sac near the deep ring and leaving the open distal sac in situ because removing whole indirect sac may increase the risk of bleeding, seroma formation, damaging cord structures, and prolonging operation. The other two patients were obese and with prolonged dissection time.

In our study all seromas resolved spontaneously without any intervention in all cases within the first two post-operative weeks. The hemostatic power and adhesive property of the glue contributed to lesser seroma rates.

In the present study we had 2 cases $(20 \%)$ of scrotal edema in group A, only one case $(10 \%)$ of scrotal edema in group B and only one case (10\%) of scrotal edema in group $\mathbf{C}$. Allcases were in patients with indirect hernias and who had a large hernia sac. It resolved spontaneously during the first 2 weeks post-operative.

In the present study and during the early postoperative period, the mean VAS scores for the glue (group B) were consistently significantly lower than those in the other groups (group A\& group C), as in the first post-operative day the pain score for group A ranged from $4.0-9.0$ on VAS with a median of 4.0 while it ranged from $2.0-4.0$ on VAS with a median of 2.50 in group B. And ranged from $3.0-6.0$ on VAS with a median of 3.0 in group $\mathbf{C}$.

After two months a degree of improvement as regard to pain in group $\mathbf{A}$ which ranged from $0.0-$ 7.0 on VAS with a median of 1.50 , pain in group $\mathbf{C}$ which ranged from $0.0-6.0$ on VAS with a median 
of 1.0 compared to group $\mathbf{B}$ which was free of pain in all patients submitting follow up (10 patients).

No additive analgesia was needed in the three groups in early post-operative period. On the other hand; five patients in group $\mathbf{A}$, three patients in group $\mathbf{B}$ and six patients in group Cneeded mild analgesia in first two months post-operative due to moderate and mild pain experience respectively after exclusion of traumatic causes by the operation.

The severity of pain during the first two month in group A reflected on the patient's need of analgesia. 35\% reported a daily use of analgesia and $30 \%$ in group $\mathbf{C}$ compared to only $15 \%$ in group $\mathbf{B}$.

As regards to Group B, the ten patients $(100 \%)$ showed a gradual improvement of pain and became a pain free by the $2^{\text {nd }}$ month post-operative.

Our results were comparable to results cultivated by literature. In a study published in 2009; which found that overall morbidity rate was $38.98 \%$ in the suture group and $10.71 \%$ in the cyanoacrylate group, the incidences of postoperative pain, local numbness and hematoma were significantly higher in the suture group than in the glue groups. Hematoma resolved spontaneously and none of the patients required reoperation, with earlier patient discharge and return to work in cyanoacrylate group proclaimed due to lesser pain and earlier movement [9].

In a preliminary study that demonstrates that the use of cyanoacrylate glue for mesh fixation and subsequently in wound closure in Lichtenstein inguinal hernia repair was safe and led to no early recurrence after early prolonged follow-up ${ }^{[10]}$.

Other study reported their first experience with cyanoacrylate glue in laparoscopic repair. Seven patients with inguinal hernia were successfully treated with mesh fixation by cyanoacrylate glue. Neither complications nor recurrence were observed. They described cyanoacrylate as an effective, inexpensive tool which helps to reduce costs in comparison to the use of staples for mesh fixation [11].

In a multicenter study reported that; the clinical outcome of cyanoacrylate glue versus non absorbable sutures for mesh fixation for Lichtenstein repair was assessed. Patients were followed-up for 1 year. As parameters of chronic pain, recurrence rate, complications and operation time were evaluated, results were operation time using cyanoacrylate glue was shorter, chronic pain was not influenced and also the complication rate was not increased in comparison to suture material ${ }^{[12]}$.

This studyfound that a significant lower pain score observed in the cyanoacrylate (cyanoacrylate) glue group compared to the suture group one day postoperatively; $p=0.0025$. A trend to less analgesic consumption and faster return to normal activity was observed ${ }^{[13]}$.

There are two studies reported their preliminary results of cyanoacrylate glue versus the use of sutureless method for mesh fixation in Lichtenstein repair; After 3 months, no recurrence was observed. Minor pain was observed after 3 weeks in 33\% patients in the sutureless group and in $18 \%$ patients in the cyanoacrylate glue group, 3 months postoperatively $16 \%$ patients in the sutureless group and 5\% patient in the cyanoacrylate glue group recorded minor pain. Local numbness was documented in $60 \%$ vs. $44 \%$ patients 3 weeks postoperatively and in $40 \%$ vs. $25 \%$ patients 3 months postoperatively in the sutureless group and cyanoacrylate group, respectively ${ }^{[14,15]}$.

Apublished study on cyanoacrylate glue fixation; conducted between 2013 and 2015. 370 patients were randomized into two groups. After randomization, 188 patients were included in the cyanoacrylate glue group and 182 in the suture group. The mean duration of operation was significantly shorter (by almost $5 \mathrm{~min}$ ) when mesh was fixed with glue. No intraoperative complications were observed. Patients remained in hospital for 48 hours and analysis of VAS pain scores demonstrated that the use of glue reduced acute postoperative pain during the early period postoperative and one month later showing significantly lower pain score in the cyanoacrylate glue group ${ }^{[16]}$.

As regard to recurrence, the widespread adoption of Lichtenstein technique has reduced the incidence of recurrence to below 5\%.In previous case series, approximately $60 \%$ of recurrences have occurred by 2 years after surgery ${ }^{[17]}$.

There was no reported cases of recurrence in group A\& group $\mathbf{B}$ and only one case of recurrence in group $\mathbf{C}$ in this present study to date. The lack of recurrences observed in our study specially as regards to group $\mathbf{B}$, strongly suggests that this mesh fixation technique followed the four key principles of the standard Lichtenstein repair: the mesh is extended approximately $2 \mathrm{~cm}$ medial to the pubic tubercle, 3-4 cm above Hesselbach's triangle, and 5$6 \mathrm{~cm}$ lateral to the internal ring, the spermatic cord is 
completely surrounded by the mesh. The strong fixative power of glue prevents movement or folding, and, finally, the mesh is always positioned slightly relaxed to avoid tension when the patient stands up from the intra operative supine position.

However other studies for glue mesh fixation reported cases of recurrence. First one with a $1.4 \%$ recurrence ${ }^{[12]}$. And the other study with a $10 \%$ recurrence rate ${ }^{[15]}$. No recurrence in group (B)was reported in our series yet.

Nevertheless, pure logic makes it impossible that detachment of the glue could occur after 6 months. In addition, cyanoacrylate, which was recognized for its hemostatic and healing properties, was also found to be useful for reduction of certain local complications, such as hematomas, seromas or wound sepsis. In this study, hematomas and seromas were not common in cyanoacrylate group, but this result was not significant. Total morbidity was less common in cyanoacrylate group but it was not significant.

For this approach, to become widespread it will need further evaluation in multicenter with controlled trials for longer time.

\section{CONCLUSION}

In summary, cyanoacrylate seemed to be a simple, original, reasonable, feasible, reproducible technique and competitive alternative to the standard tissue-penetrating mesh fixation devices in open inguinal hernioplasty. It is accompanied by a reduction in chronic inguinal pain, with no increase in the early recurrence rate. We welcome larger, preferably randomized and controlled trialsto confirm the results of this study in the future.

\section{REFERENCES}

1. Rutkow IM (2003): Demographic and socioeconomic aspects of hernia repair in the Unites States. SurgClin North Am., 83: 1045-51.

2. Amid PK (2005): Groin Hernia repair: open techniques. World J. Surg., 29(8):1046-1051.

3. Just E, Botet $\mathrm{X}$, Martínez $\mathrm{S}$, Escolà $\mathrm{D}$, Moreno I, Duque E (2010): Reduction of the complication rate in Liechtenstein hernia repair. Int J Surg., 8 (6): 462-5.

4. Canonico S, Santoriello A, Campitiello F, Fattopace A, Corte AD, Sordelli I et al. (2005): Mesh fixation with human fibrin glue (Tissucol) in open tension-free inguinal hernia repair: a preliminary report. Hernia, 9 (4):330-3.
5. Erhan Y, Erhan E and Aydede H (2008): Chronic pain after Lichtenstein and preperitoneal (posterior) hernia repair. Can J Surg., 51:383-387.

6. Klosterhalfen B, Klinge U, Hermanns B, Schumpelick V (2000): Pathologie traditioneller chirurgischer Netze zur Hernienreparation nach Langzeitimplantation im Menschen. Der Chirurg., 71(1):43-51.

7. Grisdale J (1998): The use of cyanoacrylates in periodontal therapy. J Can Dent Assoc., 64(9): 632633.

8. Hoyuela C, Juvany M, Carvajal F, Veres A, Troyano D, Trias M et al. (2017): Randomized clinical trial of mesh fixation with glue or sutures for Lichtenstein hernia repair. Br J Surg., 104(6):688-94.

9. Testini M, Lissidini G, Poli E, Gurrado A, Lardo D, Piccinni G (2010): A single-surgeon randomized trial comparing sutures, N-butyl-2-cyanoacrylate and human fibrin glue for mesh fixation during primary inguinal hernia repair. Can J Surg., 53(3):155-60.

10. Farouk R, Drew PJ, Qureshi A, Roberts AC, Duthie GS, Monson JR (1996): Preliminary experience with butyl-2-cyanoacrylate adhesive in tension-free inguinal hernia repair. Br J Surg., 83(8):1100.

11. Jourdan IC and Bailey ME (1998): Initial experience with the use of N-butyl 2-cyanoacrylate glue for the fixation of polypropylene mesh in laparoscopic hernia repair. SurgLaparoscEndosc., 8(4):291-3.

12. Paajanen H, Kossi J, Silvasti S, Hulmi T, Hakala T (2011): Randomized clinical trial of tissue glue versus absorbable sutures for mesh fixation in local anaesthetic Lichtenstein hernia repair. Br J Surg., 98(9):1245-51.

13. Nowobilski W, Dobosz M, Wojciechowicz T, Mionskowska L (2004): Lichtenstein inguinal hernioplasty using butyl-2-cyanoacrylate versus sutures. Preliminary experience of a prospective randomized trial. EurSurg Res., 36(6):367-70.

14. Helbling C, Schlumpf R, Sutureless L (2003): First results of a prospective randomised clinical trial. Hernia, 7(2):80-4.

15. Kim-Fuchs C, Angst E, Vorburger S, Helbling C, Candinas D, Schlumpf $R$ (2012): Prospective randomized trial comparing sutured with sutureless mesh fixation for Lichtenstein hernia repair: long-term results. Hernia, 16(1):21-7.

16. Hoyuela $C$, Juvany $M$, Carvajal $F$, Veres A, Troyano D, Trias M et al. (2017): Randomized clinical trial of mesh fixation with glue or sutures for Lichtenstein hernia repair. Br J Surg., 104(6):688-94.

17. Jansen PL, Klinge U, Jansen $M$ et al. (2009): Risk factors for early recurrence after inguinal hernia repair. BMC Surgery, 9(1): 18. 